\title{
FIGURY GROZY W LITERACKIEJ I MALARSKIEJ TWÓRCZOŚCI ZDZISŁAWA BEKSIŃSKIEGO
}

BOGNA KUBIŃSKA

Wydział Polonistyki, Uniwersytet Warszawski

Faculty of Polish Studies, Warsaw University

bogna.kubinska@gmail.com

\section{GROZA - PRZESTRZEŃ, POSTACI, KOLORYSTYKA}

Choć Zdzisław Beksiński zasłynął przede wszystkim jako autor obrazów (najbardziej znane są jego prace z tzw. okresu fantastycznego ${ }^{1}$, obejmującego twórczość artysty z lat 60.-90. XX wieku), jest ceniony także za fotografie, rysunki, grafiki, a nawet rzeźby. Nie jest jednak powszechnie znany fakt, że wszechstronny artysta podjął także próbę tworzenia w materii literackiej i w latach 1963-1965 zajmował się pisaniem krótkich utworów prozatorskich. O jego obrazach odbiorca może powiedzieć, że wywołują poczucie grozy²,

1 W. Banach, „Nadal szukać swojej drogi”. Zdzisław Beksiński - człowiek wielu talentów, [w:] Z. Beksiński, Opowiadania, red. T. Chomiszczak, Olszanica 2016, s. 14.

2 Anita Has-Tokarz twierdzi, że wyznaczniki gatunkowe literatury grozy są niejednoznaczne i różnorakie; zaproponowana przez nią definicja horroru głosi, że jest on: „formułą artystyczną uwarunkowaną zindywidualizowanym czynnikiem estetycznym doznawania grozy, którego realizacja dokonuje się poprzez zastosowanie - na poziomie tekstu - określonych motywów, stylistyczno-językowych środków narracyjnych, efektów dramaturgicznych (suspens, stopniowanie potencjału napięcia fabularnego) oraz kompozycyjnych (ambiwalentna struktura świata przedstawionego) podporządkowanych ewokacji atmosfery lęku i grozy u odbiorcy". Zob. A. Has-Tokarz, Horror $w$ literaturze współczesnej i filmie, Lublin 2010, ss. 31, 50. Szczególnie przydatne dla niniejszych rozważań są badania Kseni Olkusz, która omawia kategorie i zjawiska charakterystyczne dla dyskursu grozy (przestrzeń jako zagrożenie, iluzoryczna kontrola bohatera nad własnym życiem, powtarzalność i masowość pewnych czynności etc.). Zob. K. Olkusz, O grozie i postgrozie. Dyskursy - konwencja - estetyka, [w:] Groza i postgroza, red. K. Olkusz, B. Szymczak-Maciejczyk, Kraków 2018, s. 15-52. 
lęku, ich atmosfera jest przygniatająca. Podążanie za odczuciami wywołanymi przez dzieło jest zgodne z tym, co Beksiński uważał za najistotniejsze w procesie odbioru obrazu, a mianowicie, że nie trzeba - lub wręcz nie powinno - koncentrować się na interpretacji tego, co przedstawione ${ }^{3}$. Należy jedynie zbliżyć się do obrazu dzięki emocjom, jakie budzi. Już sam kontakt z dziełem wystarczy, by zanurzyć się w świecie wytworzonym przez artystę. Obraz powinien być według Beksińskiego przeżywany, nie - rozumiany. Podobne odczucia lęku wywołuje proza twórcy. Niepokój, zagubienie, niepewność towarzyszą czytelnikowi od początku do końca każdego opowiadania. Artysta jest mistrzem w budowaniu napięcia, które nie zostaje ostatecznie rozładowane, czego mógłby i chciałby spodziewać się czytelnik. Brak tu nagłych zwrotów akcji czy rozbudowanej fabuły - akcja jest zarysowana tak skromnie, tak zalążkowo, że można by ją w całości uwiecznić na obrazie. Tym właśnie są opowiadania Beksińskiego: relacjonowanymi kawałek po kawałku scenami rodem ze statycznego obrazu, żonglują emocjami odbiorcy, lecz nie przynoszą katharsis związanego z finalnym przebiegiem zdarzeń. Pozostawiają czytającego z wywołaną przez nie trwogą. Statyczność świata przedstawionego w opowiadaniach sprawia, że ich koniec to koniec czysto formalny, nie fabularny. Ową grozę malarskiej i literackiej twórczości Beksińskiego tworzą różnorakie figury - zbadanie ich, a także ich reprezentacji w obu dziedzinach sztuki uprawianych przez artystę jest przedmiotem niniejszego artykułu. Na szczególną uwagę zasługują zwłaszcza transpozycje medialne, tj. działania artysty polegające na wprowadzaniu do danego medium reprezentacji figur typowych dla innego medium.

Twórczość Beksińskiego odsyła do kategorii przemilczenia nierozwiązalnego, które - jak pisze Brygida Pawłowska-Jądrzyk - „polega na utajnieniu - determinujących egzystencję bohaterów danego utworu - przyczynowych wiązań motywacyjnych między przedstawionymi zdarzeniami (i prowadzi nieuchronnie do przemilczeń dotyczących innych aspektów dzieła, takich zwłaszcza, jak konstrukcja fabuły czy konstrukcja postaci)” oraz stanowi

3 Artysta nie uwzględniał przy tym, że proces interpretacji odbywa się w sposób niezaplanowany, niekontrolowany i że wszystko, co dociera do człowieka, jest interpretowane. Zob. R. Nycz, Tekstowy świat. Poststrukturalizm a wiedza o literaturze, Kraków 2000, s. 83-120; E. Szczęsna, Poetyka mediów. Polisemiotyczność, digitalizacja, reklama, Warszawa 2007, s. 169-192. 
według badaczki rodzaj elipsy (nazywanej przez nią „wielką”) ${ }^{4}$. Kategoria przemilczenia służy, według Stefanii Skwarczyńskiej, „,do wyrażenia kategorii metafizycznych w dziele literackim. Tajemniczość, której wyraz dają przemilczenia we wszystkich warstwach dzieła, jest podkreśleniem czynników irracjonalnych i ich wagi w budowie świata"5. W twórczości Beksińskiego przemilczenie nierozwiązalne ma wartość figury tekstowej.

Obrazy i opowiadania artysty są pełne tajemniczości. Sprawia ona, że czytelnik chce dopowiedzieć owe zagadkowe, nierozwiązalne historie, wytłumaczyć je, zinterpretować; okazuje się to niemożliwe, w związku z czym niedosyt prowadzi odbiorcę do kolejnego opowiadania (lub obrazu). I mimo kolejnych minut spędzonych z ową twórczością, nienasycenie trwa, pojawiają się pewne próby interpretacji, lecz trudno o historie dopowiedziane, zrozumiałe.

Emocje, odczucia, myśli to bardzo ważna część twórczości Beksińskiego. Miały one znaczący wpływ na proces malowania: obrazy artysty nie były planowane, powstawały pod wpływem chwili, były przez niego przerabiane, warstwa pojawiała się na warstwie, symbol na symbolu. Wydaje się, że z opowiadaniami jest podobnie. Warto jednak wskazać pewne tropy, które mogą okazać się pomocne przy próbach zrozumienia i skategoryzowania twórczości artysty. Charakterystyczna dla Beksińskiego groza jest zjawiskiem oryginalnym; zarówno narzędzia, które ją budują, jak i oddziaływanie niej samej na poetykę tekstu artystycznego warte są przeanalizowania. Z uwagi na podobieństwo środków wyrazu kształtujących grozę w opowiadaniach i w obrazach można mówić o transmedialnych figurach grozy w twórczości Beksińskiego. Owe figury współistnieją ze sobą, wchodzą we wzajemne interakcje w procesie tworzenia niepowtarzalnego, właściwego tylko Beksińskiemu świata grozy. Co ciekawe, owa wytworzona przez konkretne narzędzia groza oddziałuje na nie i przekształca efekt ich działania na nią, co stanowi swoiste perpetuum mobile twórczości Beksińskiego.

4 B. Pawłowska-Jądrzyk, Wielka elipsa w narracji literackiej i filmowej („Piknik pod Wiszącą Skała"), [w:] Komparatystyka dzisiaj, red. E. Kasperski, E. Szczęsna, Warszawa 2011, s. 89.

5 S. Skwarczyńska, Przemilczenie jako element strukturalny dzieła literackiego, [w:] Z teorii literatury. Cztery rozprawy, Łódź 1947, s. 26 [cyt. za: B. Pawłowska-Jądrzyk, op. cit., s. 88]. 
W tym procesie (artystycznego użycia) figury te przestają być strukturami uniwersalnymi, a stają się strukturami osobowości twórczej Beksińskiego odzwierciedlającymi indywidualny świat jego wyobraźni. W niniejszym artykule skoncentruję się na analizie tego, jakie figury budują grozę - tak w obrazach, jak w opowiadaniach artysty.

Trzema fundamentalnymi kategoriami opowiadań i obrazów Beksińskiego - zwłaszcza w kontekście wywoływanej przez nie grozy - są przestrzeń, postaci i kolorystyka. Zdają się najważniejszymi obszarami niosącymi znaczenia, emocje i symbole. Właśnie w tych trzech sferach wspomniane figury znalazły największe zastosowanie. O ile waga tych trzech zagadnień w przypadku obrazów jest wytłumaczalna i dostrzegalna, ponieważ malarstwo w swej istocie eksponuje te właśnie pola, o tyle należy objaśnić zasadność wskazania tych kategorii jako istotnych w odniesieniu do opowiadań. W dwudziestu pięciu opowiadaniach i szkicach Beksińskiego, udostępnionych polskiemu czytelnikowi w zbiorze wydanym w 2016 roku $^{6}$, przestrzeń odgrywa ważną, jeśli nie najważniejszą, rolę. Utwory te często rozpoczynają się od opisu, nakreślenia przestrzeni lub ustosunkowania się do niej narratora. W wielu z nich znaczenie przestrzeni ujawnia się nie tylko na początku - często okazuje się ona osią kompozycyjną utworu. Konstytuuje postaci, jest przedmiotem rozważań, analizy podmiotu mówiącego. Decyduje o ruchach, jakie te postaci wykonują, o ich działaniach, rolach, które odgrywają. Tak np. w opowiadaniu Zamach bohaterka - kobieta $\mathrm{z}$ kiosku - nie została w żaden sposób opisana czy przedstawiona, czytelnik nie poznaje jej imienia; jego uwaga zostaje skupiona na falowaniu i kołysaniu jej pleców związanym z przestrzenią, w której kobieta się znajduje ${ }^{7}$, co ją definiuje i stwarza jedyny rys tej postaci. Początkowo narrator zdaje się poddawać skojarzeniu wynikającemu z kontekstu sytuacyjnego - wiąże kołysanie pleców z myciem podłogi lub układaniem czegoś na półkach. Sy nekd o cha (plecy jako reprezentacja kobiety) użyta w celu wprowadzenia postaci sprawia, że bohaterka jest tajemnicza i niepoznawalna, wywołuje grozę. Jednocześnie realność związku kobiety i podłogi

6 W sumie całość dorobku prozatorskiego autora liczy „20 opowiadań, 20 fragmentów oraz 17 pomysłów”. Zob. T. Chomiszczak, Nota wydawnicza, [w:] Z. Beksiński, op. cit., s. 412 .

7 Z. Beksiński, Zamach, [w:] op. cit., s. 209. 
zostaje wyparta przez czynnik metafizyczny, jaki wprowadza pr ze nośn ia „falowanie pleców”. W tym przypadku obie figury zastosowane zostały w celu wzmocnienia efektu grozy. Powodują one, że sam pierwszoosobowy narrator zaczyna analizować ruch pleców, co prowadzi go do coraz bardziej absurdalnych hipotez na temat źródeł tego ruchu. W pewnym momencie zastanawia się nawet, czy owo falowanie nie jest związane z rozmawianiem z kimś ukrywającym się w kiosku i leżącym na jego dnie ${ }^{8}$ (tworząca się tutaj groza narasta i kumuluje napięcie, rezonuje nie tylko na obszar wyobraźni odbiorcy, ale i samego narratora). Groza zaczyna przeczyć rzeczywistej relacji między dwoma obiektami i wnosi czynnik metafizyczny (falowanie pleców, ale i wprowadzenie pierwiastka tajemnicy, niezwykłości, zmowy do kontekstu codzienności). W Kobiecie z portretu pierwsze zdanie rozpoczyna się zwięzłym opisem miejsca, w którym rozgrywa się akcja całości: „Mój fotel stoi po przeciwnej stronie ściany, na której wisi kopiowany portret"9 Podobnie jest w pozostałych opowiadaniach - przestrzeń wysuwa się na pierwszy plan.

Przestrzeń przedstawiana przez Beksińskiego ma pewne elementy niezwykłości. Przede wszystkim jest wymiarem dominującym w świecie kreowanym przez artystę. Jest siłą i źródłem niepewności, pełna mroku, pustki, tajemniczości. Podobnie jak w malarstwie, w prozie sanoczanina ukazywane miejsca są bardzo często pełne grobów, opuszczonych budynków, mgły, ciemnych i ciasnych korytarzy. W obu obszarach twórczości Beksińskiego przestrzeń jest złowroga i nieoczywista, nie do końca poznana i niedająca się poznać (il. 1$)^{10}$.

8 Ibidem.

9 Idem, Kobieta z portretu, [w:] op. cit., s. 332.

10 Zdzisław Beksiński nie tytułował swoich prac, a nawet unikał ich datowania. Wynikało to z przekonania artysty, że podawanie tych informacji może znacząco wpłynąć na proces odbioru jego twórczości i go zaburzyć. Z tego względu obrazy przytaczane w niniejszym artykule nie są opatrywane tytułem ani datą. 
Pada śnieg. To, co znajduje się w zasięgu wzroku, a więc nagie zimowe drzewa, betonowe płyty grobowców, poszarzałe resztki trawy, to wszystko pokryte jest teraz równomiernie białym rastrem śniegu [...] $]^{11}$.

Zarówno przestrzeń zamknięta, jak i otwarta budzi niepokój. Kiedy są to budynki, pomieszczenia, pokoje, w których znajduje się bohater lub kilku bohaterów, stanowią one rodzaj pułapki i więzienia, z których nie da się wydostać - czasem z powodu przeszkód fizycznych, a czasem - psychicznych. W owych pułapkach często znajduje się element graniczny - okno lub wyjście, które dają widok na otoczenie, na to, co nieosiągalne, ale także nieobiecujące (il. 2-3).

Więc idę ulicą [...]. Wokół jakieś ruiny i rusztowania. Ulica jest [...] tak ciasna, że muszę się przepychać, aby móc zdążyć. Ściany domów, rusztowania zaciskają się po obu stronach, przejście wynosi zaledwie pół metra [...]. Nie mogę się cofnąć; nie wiem właściwie dlaczego, lecz nie mogę się cofnąćc ${ }^{12}$.

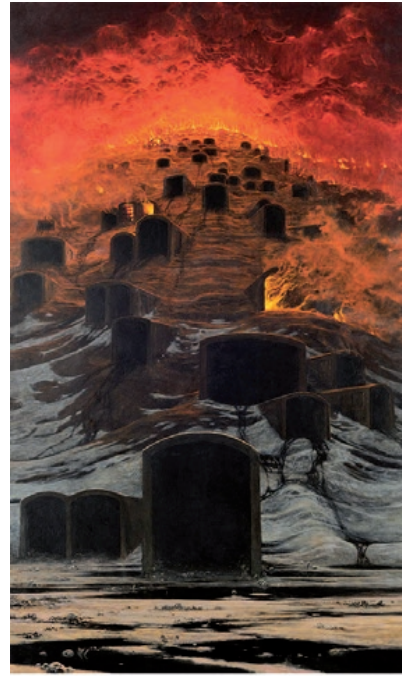

Il. 1
Z kolei kiedy przestrzeń jest otwarta, przytłacza swoim bezkresem, zniszczeniem i pustką. Zwraca uwagę taki sposób opisywania przestrzeni otwartej i naturalnej, który za pomocą dobranego słownictwa, zwykle epitetów stanowiących jednocześnie swoistą p r ze nośn i ę, tworzy z niej przestrzeń zamkniętą i będącą efektem działań człowieka: „Nad polem wznosi się czarny sufit nocnych chmur”'13; „Na końcu ogrodu, pod liśćmi łopianu, jest cichy, wilgotny kąt"14.

W opowiadaniach Beksińskiego nie znajdzie się wielu typowych dla literatury figur retorycznych; teksty literackie artysty cechują się zaskakującym ubóstwem w tej materii, z tego względu każda zastosowana przez autora przenośnia czy epitet zdają się przemyślanymi

11 Idem, Śnieg, [w:] op. cit., s. 188.

12 Idem, Na końcu ogrodu, [w:] op. cit., s. 28.

13 Ibidem, s. 23.

14 Ibidem, s. 28. 


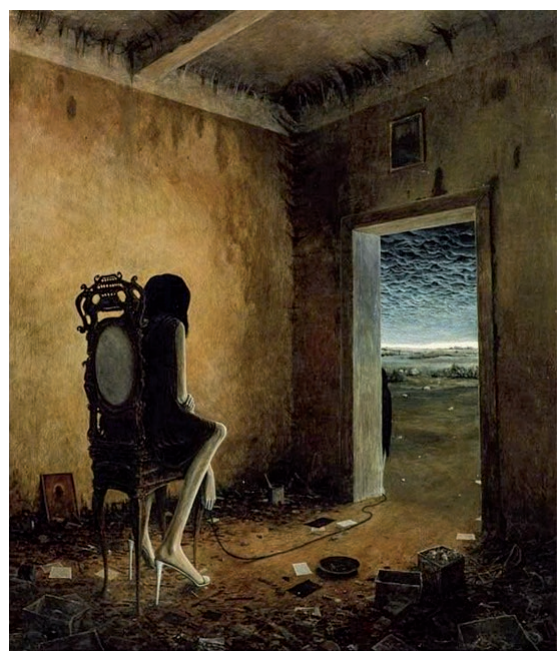

Il. 2

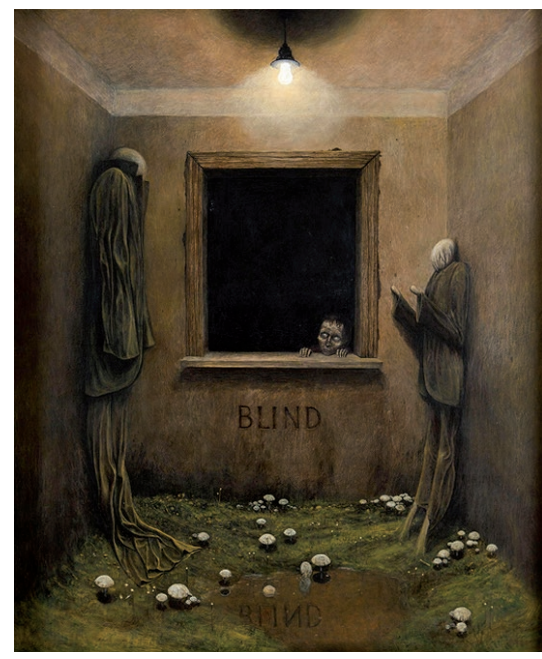

Il. 3

narzędziami budującymi grozę tej twórczości. W tym wypadku służą takiemu przedstawieniu przestrzeni, która złożona jest $\mathrm{z}$ dwóch porządków będących w ciągłej walce ze sobą. Kultura i natura stale się przenikają, jedna drugą naśladuje, lecz wydaje się, że ostatecznym zwycięzcą jest natura - ta, której częścią jest śmierć zabierająca każdego z tego pozornie zaplanowanego, wybudowanego przez człowieka świata. U Beksińskiego natura dominuje nad cywilizacją, porasta ją, pożera, doprowadza do tego, że miasta giną, płoną, budynki się zapadają. Cykliczność świata i życia jest bezwzględna, a postaci są wątłymi drobinami jej poddanymi.

W opowiadaniach i na obrazach Beksińskiego dostrzegalne są surrealistyczne zapędy i fascynacje twórcy. Czas jest w jego twórczości kategorią względną. Nie jest znana do końca pora roku, o której niekiedy można wnioskować tylko na podstawie wyglądu otoczenia, co może okazać się zgubne Beksiński łączy bowiem ze sobą zjawiska, które w rzeczywistości nie mają prawa się połączyć. Rzadko kiedy upewnia odbiorcę w tym, co widzi. Sam zresztą nieustannie podejmuje w swoich pracach temat względności tego, co widziane, doświadczane, niewiary w możliwości zmysłów. Narrator opowiadań często próbuje dociec prawdy o czasie i miejscu, posługując się logiką, analizą, wiedzą. Jednak nie sposób otrzymać odpowiedzi, która potwierdzałaby domysły odbiorcy (i narratora) lub im przeczyła. Beksiński ukazuje 
świat jako coś, co być może jawi się każdemu w inny sposób, jako wytwór niezłomnej wiary człowieka w konkretne wyobrażenie. Malarstwo artysty także pozostawia odbiorcę $\mathrm{w}$ niepewności co do czasu ukazanych przedstawień. Nie ma pewności, czy to dzień, czy noc, świat jest albo połączeniem wszystkich czasów jednocześnie, albo znajduje się zupełnie poza tą kategorią.

Widać to chociażby na przedstawionym poniżej obrazie (il. 4): w budynku panuje czas dnia, jesieni, może wczesnej wiosny, ponieważ widoczne rośliny są pozbawione liści, a jednocześnie trawa jest już (lub jeszcze) zielona. W oknie i wyjściu natomiast - czas nocy, być może letniej, ponieważ gwiaździstej. Na zewnątrz wreszcie - trudna do określenia pora dnia i roku. Mrok i ciemność, tak częste w twórczości Beksińskiego, nie muszą świadczyć o tym, że jedyny słuszny czas, jaki można wskazać, to noc. Przedstawianie kilku przestrzeni i czasów jednocześnie wpływa na poczucie niepewności odbiorcy.

Surrealistyczne są także już same rodzaje opisywanych czy malowanych miejsc. Obrazy i opowiadania są oniryczne, obfitują w elementy fantastyczne; ryby latają, księżyc widnieje na wysokości linii horyzontu, wielkie wiklinowe schody nie prowadzą w jednym określonym kierunku, nie wiadomo nawet, gdzie się znajdują. Przykłady można by mnożyć. Sam narrator (zwykle pierwszoosobowy) nigdy nie jest pewien, czy coś dzieje się na jawie, czy we śnie,

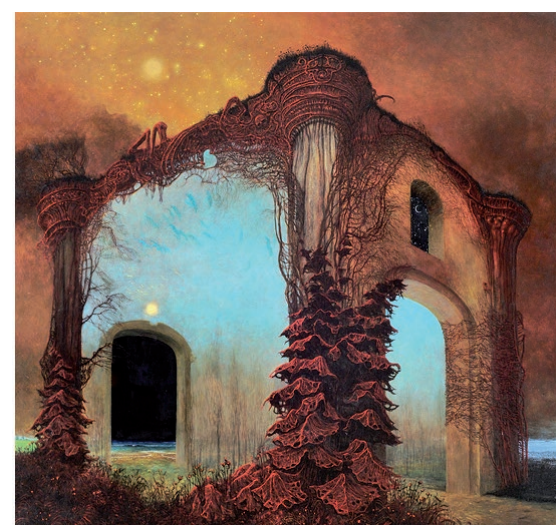

Il. 4 a być może tylko w jego wyobraźni lub przywidzeniu.

Poza tym jestem w trakcie mych podróży zupełnie sam i sądzę, że domy, pełgające światełka i wydeptane trakty, do których dążę, są również niezamieszkane, bezosobowe, anonimowe, nieuczęszczane, [że to] fatamorgana, złudzenie, iluzja w iluzji, sen w marzeniu sennym ${ }^{15}$.

15 Ibidem, s. 24. Dopisek w nawiasie kwadratowym pochodzi od redaktora zbioru opowiadań. 
Przestrzeń Beksińskiego to także powrót do przeszłości, często do przeżytych traum. Artysta płynnie porusza się między rzeczywistością a nierzeczywistością, wspomnieniem, wyobrażeniem a faktem dziejącym się tu i teraz, stale utrzymuje odbiorcę na granicy iluzji. To istotnie podważa pewność odbiorcy co do tego, co się właściwie wydarzyło, wydarza lub ma wydarzyć. Zobaczony przez postać przedmiot może przenieść czytelnika do świata jej wspomnień (np. pociąg kojarzy się bohaterowi z pogrzebem $o^{o j c a^{16}}$ ), z którego nie wiadomo, kiedy i czy postać się wydostaje. Poza tym przestrzeń ta pełna jest symboli odpowiadających układowi góra-dół ${ }^{17}$ : na górze umieszczone są rzeczy dobre, lecz nieosiągalne, na dole - złe, bliskie bohaterowi (np. w poniższym fragmencie włączniki światła znajdują się na wysokości nieosiągalnej dla dziecka, na dole zaś są złośliwe krasnoludki źródło strachu bohatera).

Mam dopiero siedem lat. W pokoju na końcu amfilady nie pali się światło i gdy idę po zostawione w pokoju zabawki, muszę przejść przez sześć nieoświetlonych pokoi. Wyłączniki światła są na wysokości półtora metra. Nie mogę do nich dosięgnąć bez dostawienia do ściany krzesła lub stołeczka. Za poręczami krzeseł, pod blatami stołeczków czekają na mnie złośliwe krasnoludki. Małe stworzonka o nieokreślonym kształcie. Gdy po omacku szukać będę krzesła, mogę dotknąć jednego z nich. W ciemnym otworze, $\mathrm{w}$ ciemnej szczelinie za piecem goreje dwoje oczu, na pewno goreje dwoje oczu; nie mogę obrócić głowy, bo je zobaczę. Nie mogę obrócić głowy, bo je zobaczę, a jednak muszę obrócić głowę i muszę je zobaczyćc

Bywa też, że przestrzeń wykreowana jest na przekór temu utrwalonemu porząakowi. Znów Beksiński przeciwstawia się temu, co teoretycznie pewne i znane, lecz - jak się okazuje - niekoniecznie trwałe czy zawsze słuszne.

Postaci ukazywane w malarstwie i te nakreślone w utworach literackich Beksińskiego różnią się od siebie. O bohaterach obrazów artysty można powiedzieć, że są to twory antropomorficzne, które czasami mają cechy

16 Idem, Zamach, [w:] op. cit., s. 205.

${ }_{17}$ Więcej na temat kulturowo utrwalonych znaczeń relacji góra-dół zob. np. Y.F. Tuan, Ciało, relacje międzyludzkie i wartości przestrzenne, [w:] idem, Przestrzeń i miejsce, tłum. A. Morawińska, Warszawa 1987, s. 51-70.

18 Z. Beksiński, Na końcu ogrodu, [w:] idem, op. cit., s. 24. 
wspólne z innymi organizmami żywymi (np. gadzi lub owadzi sposób poruszania się). Są to stwory pokaleczone, składające się głównie z kości, ścięgien i skóry, pozbawione typowych cech ludzkich (elementów twarzy, mimiki i w związku z tym - emocji) umożliwiających identyfikację. Przedstawione $\mathrm{w}$ ten sposób stają się anonimowe ${ }^{19}$, nieodgadnione. Są bytami na granicy życia i śmierci, zdeformowanymi lub zmutowanymi. Czasem trudno określić ich płeć czy wiek - choć często można dostrzec sugestię, że ci bohaterowie to kobiety czy dzieci, kojarzące się z delikatnością czy niewinnością. Przez tę a lu zję efekt grozy jest zwielokrotniony. Ci bohaterowie różnią się od naturalnego, zakorzenionego w umyśle ludzi obrazu człowieka, a jednocześnie bardzo go przypominają ${ }^{20}$. Takie użycie figury aluzji wywołuje dyskomfort. Często przygarbieni, ze zwieszoną głową, skuleni - jakby bezsilni czy bezwładni. Beksiński kolejny raz zderza ze sobą światy wytworzone przez kulturę i naturę. Sadystyczny sposób przedstawiania postaci wywołuje trwogę, zwłaszcza u osób ukształtowanych przez kulturę szacunku do ciała i pewnej jego świętości, nienaruszalności, intymności² ${ }^{21}$. Jednak z perspektywy sadysty emocje wywoływane przez obrazy mogłyby być zupełnie inne, zapewne przyjemne - tę różnorodność pojmowania świata

19 W ten sposób autor kolejny raz pozostawia odbiorcę samego z jego refleksjami i odczuciami. Nie sugeruje, jak odbierać obrazy, nadaje im wieloznaczność, odbiorca sam musi zdecydować, jaką postawę przyjąć.

20 Źródła lęku można się tutaj dopatrywać w zjawisku pokrewnym „dolinie niesamowitości” - termin ten oznacza dyskomfort lub wręcz lęk w kontakcie z nieożywionym przedmiotem humanoidalnym; według badaczy podejmujących ten temat lęk jest wywoływany przez zamazywanie się granicy pomiędzy człowiekiem a tworem sztucznym (zob. np. Ł. Sarowski, Robot społeczny - wprowadzenie do zagadnienia, „Roczniki Kulturoznawcze” 2017, nr 1, s. 84). Jak wskazuje Ewa Wójtowicz: „choć w zasadzie pojęcie to stosowane jest w odniesieniu do przedstawień antropomorficznych, prawdopodobnie zjawisko, które określa, dotyczy także wizerunków zoomorficznych bądź hybryd" (zob. E. Wójtowicz, W stronę doliny niesamowitości, [w:] Bio-techno-logiczny świat: bio art oraz sztuka technonaukowa $w$ czasach posthumanizmu i transhumanizmu, red. P. Zawojski, Szczecin 2015, s. 25).

${ }^{21}$ „Groza wywoływana jest zwykle przez czynniki kulturowe, które nadają określony rodzaj interpretacji otaczającym nas zdarzeniom” - zob. B. Płonka-Syroka, Wstęp, [w:] Groza. Społeczno-kulturowe mechanizmy kreowania emocji, red. B. Płonka-Syroka, M. Szymczak, Wrocław 2010, s. 7. 
przez ludzi zauważał sam artysta. Dostrzegał, że rozumienie rzeczywistości jest wytworem kultury, doświadczeń, przeżyć, spotkanych ludzi, wykonywanych zawodów i że często kultura ta nakładana jest na naturę, skłonności i odruchy człowieka. Jest to stałe ścieranie się tych dwóch pierwiastków. Beksiński prowokował swoją sztuką. Z jednej strony przedstawiał postacie anonimowe, jako tłum dążący do tego samego, mający te same marzenia, wykonujący te same czynności ${ }^{22}$. Z drugiej ukazywał inność, niekonwencjonalne rytuały i zwyczaje bohaterów. Fakt, że szokowało to i niepokoiło odbiorców, był dla artysty zajmujący.

„Koszmarna wizja świata?”. A cóż to jest świat? Należałoby o to zapytać starca nad grobem lub człowieka ze zmiażdżonym kręgosłupem, umierającego w szpitalu, lub polityka w okresie zagrożenia wojną - za każdym razem otrzymalibyśmy inną wersję słowa „świat”. W tym sensie i ja mam swój świat...23.

Poczucie grozy, jakie wywołują bohaterowie malarstwa, nie polega na lęku przed nimi. Odbiorca nie boi się ich, lecz utożsamia się z nimi - dopiero pod wpływem obserwacji zaczyna odczuwać niepokój. Co zatem wywołuje lęk? Jest to wspomniana wcześniej przestrzeń i zależność człowieka od niej; źródło niepewności, nierzadko świat po zagładzie, iluzoryczność i kruchość życia (np. il. 5).

Natomiast, jeśli chodzi o bohaterów opowiadań, trzeba zaznaczyć, że niewiele można dowiedzieć się na temat ich wyglądu. W związku z tym czytelnik automatycznie wyobraża sobie zwykłych ludzi, nie straszy go ich aparycja, sugerująca, po jakich są przejściach. Beksiński szczędzi opisów bohaterów - nie tylko nie przybliża ich fizyczności czytelnikowi, lecz także nie rozbudowuje ich rysu psychologicznego, nie nadaje im wielu cech, nie skupia się na nich. Te postaci są zawieszone w tu i teraz opowiadania, nie jawią się jako żyjący codziennością ludzie, lecz jako pionki, elementy większej całości, jakiegoś obrazu, jako uczestnicy gry zwanej życiem. Postaci są tajemnicze, niedookreślone, anonimowe - nazywane przez pryzmat tego, co aktualnie

${ }^{22}$ Jest tak np. w opowiadaniu Bakterie, zob. Z. Beksiński, Bakterie, [w:] idem, op. cit., s. 118.

${ }^{23}$ Wypowiedź Beksińskiego w wywiadzie. Zob. H. Brzozowski, Odnaleźć w sercu i pod powiekami, „Tygodnik Powszechny” 1977, nr 25, s. 6. 


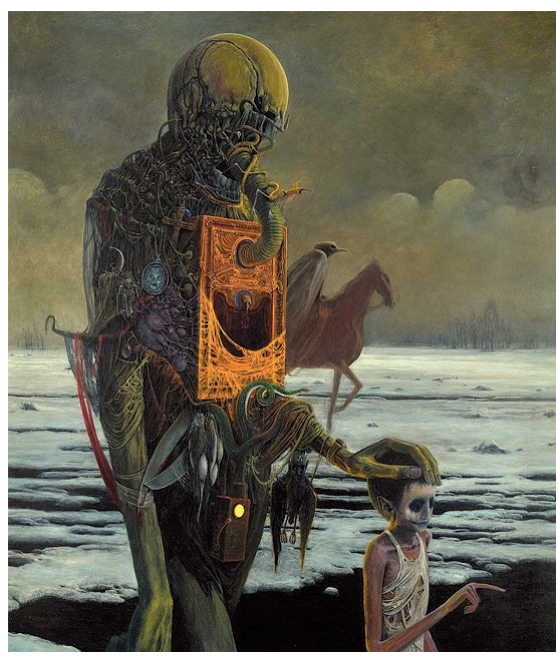

Il. 5

robią, do czego zmusza je otoczenie, przez wzgląd na role czy funkcje, a nawet na przypisany im rekwizyt, np.: Obserwator, Kobieta, Autor, Widz, Numer Szesnasty, Informator, Podpalacz, Człowiek w okularach. Postaci często są obserwowane lub obserwują. Są zagubione, nawet sam narrator (najczęściej będący głównym bohaterem) nie tylko nie jest wszystkowiedzący, lecz także nie jest pewien rzeczy fundamentalnych czy coś się dzieje naprawdę, czy coś istnieje, czy nie. Czasami wychodzą na jaw psychiczne problemy czy wręcz zaburzenie bohatera ${ }^{24}$. Tak jest w opowiadaniu $\mathrm{Na}$ końcu ogrodu, które jest skonstruowane na wzór rozmowy z psychoterapeutą. Co ważne, opowiadanie to otwiera zbiór, a więc już od samego początku lektury wprowadza wątek wyjątkowości świata i postaci kreowanych przez Beksińskiego. W opowiadaniu Manekiny ${ }^{25}$ bohater, starzec, jest maniakiem, fetyszystą i degeneratem, a sensem jego egzystencji jest współżycie z manekinami. Kaleki, samotnicy, ludzie po przejściach, zaburzeni - to front osobowości w opowiadaniach Beksińskiego.

Idę ogrodem, parkiem lub cmentarzem. [...] W niesłychanym natłoku liści [...] znajduje się miejsce, do którego [...] wbrew woli podążam. Nie wiem,

24 Ksenia Olkusz wskazuje za Stevenem Bruhmem, że „współczesna estetyka gotycka operuje nie tyle psychoanalizą w sposób przedmiotowy, ile raczej wyzyskuje ją w konstruktach narracyjnych”. Gotycyzm świata Beksińskiego nie jest przedmiotem analizy niniejszego artykułu, jednakże jego elementy są dostrzegalne w twórczości artysty i korespondują z zagadnieniami grozy i niepokoju, które podejmuję w kolejnych akapitach. Takie motywy, jak narrator czy bohater z zaburzeniami psychicznymi, to rozwiązania pojawiające się w opowiadaniach Beksińskiego. Zob. K. Olkusz, Gotyckie światy współczesnej grozy, [w:] Światy grozy, red. K. Olkusz, Kraków 2016 s. 17.

25 Z. Beksiński, Manekiny, [w:] idem, Opowiadania, s. 287. 
jak wygląda to miejsce; wydaje mi się, że jest to chyba grób, grobowiec. [...] Może mówię zbyt wiele, mówiąc równocześnie zbyt mało. Nie wiem, czy odczuwam to we śnie tak jak w tej chwili. [...] Czy mam jeszcze mówić? Mów dalejé.

W innym fragmencie czytamy: „Człowiek w okularach otrząsa się. [...] Scena ta jest obserwowana. Obserwatorem jest człowiek wyposażony w lornetkę"27. Bohaterowie znowu okazują się mało istotni z perspektywy ogromu świata i siły natury. Kolejny raz poruszają się po świecie po omacku, próbują dostosować się do życia w określonych warunkach. Nie znaczą wiele, trudno ich odróżnić od siebie, są zdeformowani (jak na obrazach) albo psychicznie, albo fizycznie. Odbiorca nie widzi tej deformacji, jedynie czuje ją i to, jak ona wpływa na jakość życia postaci. Niewiele wie o ich przeszłości, niewiele o przyszłości. Bohaterowie tkwią, jak już wcześniej zostało ustalone - w mnogości czasów lub zupełnie poza czasem.

Mieszkanie starca zajmuje dwie kondygnacje. Stary jest kaleką, ma sparaliżowane nogi, może w ogóle nie ma nóg, bo stracił je na wojnie lub w wypadku samochodowym; zresztą możliwe jest także i to, że symuluje bezwład nóg, skłoniony do tego sobie tylko wiadomymi powodami - w każdym razie starzec porusza się wprawdzie o siłach, lecz tą siłą jest siła rąk, które obracają korbę wózka na wielkich szprychowych kołach sunącego po czerwonym dywanie niższej kondygnacji ${ }^{28}$.

Kolorystyka to ostatni z wymienionych elementów, który ma duże znaczenie w twórczości Beksińskiego. Artysta w swoich opowiadaniach nie poświęca wiele uwagi nazywaniu kolorów widzianych rzeczy. Wydaje się to zaskakujące, ponieważ operowanie pełną gamą barw przypisuje się zwłaszcza malarzom. W opowiadaniach czasem wspomina się o kolorach, ale ważniejsze jest wydobycie tego, które przedmioty i miejsca są ciemne, a które jasne. Ko n t ra st to także stały element obrazów Beksińskiego. Jedną z dróg interpretacji podziału właśnie na ciemne i jasne może być podążanie za funkcjonującymi w kulturze skojarzeniami, wartościami. Ciemność może znaczyć niepewność, obcość, strach, zagubienie; jasność - nadzieję,

26 Idem, Na końcu ogrodu, [w:] op. cit., s. 31-32.

27 Idem, Śnieg, [w:] op. cit., s. 188.

28 Idem, Manekiny, [w:] op. cit., s. 288. 
dobro, bezpieczeństwo. Na wielu obrazach wyraźnie widoczna jest taka gra kolorami, że odbiorca zwraca uwagę na jasne i ciemne punkty. Kolory w tekstach Beksińskiego wprowadzane są albo wprost, albo w sposób implikowany - mogiła, grób, loch kojarzą się z ciemnością, promienie słoneczne, śnieg - z jasnością. W opowiadaniach stale powtarzającymi się barwami są biel i czerń. Ilustrują to poniższe fragmenty opowiadania Na końcu ogrodu:

Mrok rozpościera się nad ziemią, ale jest to dziwny mrok, pokrywający ziemię do wysokości trawy. Trawa, glina, chwasty, łopiany, patyki koraliny są mroczne, jak przysypane grubą warstwą pyłu węglowego. Mrok panuje nad samą ziemią. Niebo natomiast jest stosunkowo jasne, pokryte czerwienią zachodu ${ }^{29}$.

Na obrazach można zaobserwować podobne zabiegi; jednak w przypadku malarstwa, zwłaszcza okresu fantastycznego, który w odniesieniu do twórczości Beksińskiego rozpoczął się ok. 1964 roku, czyli w okresie prób prozatorskich artysty, wręcz barokowe nagromadzenie różnych kolorów jest dostrzegalne. Światło i cień rządzą się swoimi prawami zarówno w malarstwie, jak i w prozie Beksińskiego. Światło nie pojawia się tam, gdzie powinno, rozświetlone zostają miejsca, które - w zgodzie z prawami fizyki - nie mają prawa być oświetlone. Przez to następuje także pomieszanie czasowe - nieznane są pory dnia (czasem roku), mrok niekoniecznie musi oznaczać noc, a jasność - dzień. Przestrzeń wpływa zatem na postrzeganie czasu świata przedstawionego w dziełach twórcy. Ilustruje to także zdanie pochodzące z tego opowiadania: „Przeszłość jest ciemna”30. Można zatem stwierdzić, że artysta w większej mierze operuje światłocieniem w opowiadaniach niż na obrazach, na których dostrzec można czerwień, zieleń, żółć i inne żywe kolory (te, co prawda, zwykle są przydymione, mroczne, brudne). Beksiński-malarz nie szczędzi szczegółu, maluje swoje obrazy z rozmachem, jednak rozmycie niektórych barw, mglistość, niejednoznaczność wprowadzają zamęt interpretacyjny. Natomiast Beksiński-pisarz zupełnie odwrotnie: czytelnik zdany jest na swoją wyobraźnię, która może być znacznie mniej mrocznie ukierunkowana niż wyobraźnia artysty. Jednak przez to,

29 Idem, Na końcu ogrodu, [w:] op. cit., s. 21.

30 Ibidem, s. 26. 
że Beksiński tak niewiele daje w opowiadaniach, podtrzymuje w czytelniku poczucie zagubienia, niedookreśloności.

To dość dokładne przyjrzenie się trzem istotnym obszarom twórczości Beksińskiego pozwala na zaobserwowanie pewnych cech i tendencji, które sprawiają, że wspomniana wcześniej wielka elips a opisana przez Pawłowską-Jądrzyk znów powinna zostać przytoczona w niniejszym artykule. Badaczka wymienia szereg zależności, które decydują o tym, czy może być mowa o występowaniu elipsy w dziele literackim (i filmowym). Na podstawie ustaleń badaczki rozszerzę występowanie tej figury także na obszar malarstwa, gdyż obrazy Zdzisława Beksińskiego całkowicie dają się analizować pod tym kątem. Otóż według literaturoznawczyni szczególną uwagę należy zwrócić na fakt, że występowanie wielkiej elipsy w tekście artystycznym wiąże się z przemilczeniami, które objawiają się tajemniczością, stłumieniem, a te natomiast stanowią fundament twórczości Beksińskiego. Wspomina ona także o dyskursie onirycznym, surrealistycznym (ten wręcz wpływa na zwiększenie miejsc niedopowiedzianych), a także o obecnych „częstych i radykalnych zmianach czasowo-przestrzennych”, będących kanonicznym elementem budowania napięcia i niosących nowe znaczenia pod postacią symboli ${ }^{31}$. Na obecność wielkiej elipsy w tekście wskazuje również zmienny zasięg wiedzy narratora, który to u Beksińskiego raz wie znacznie więcej, niż to możliwe $z$ jego perspektywy ${ }^{32}$, a raz nie potrafi ocenić sytuacji w kwestii najbardziej fundamentalnych zagadnień (czy śni, czy jest na jawie; czy coś istnieje, czy nie). To natomiast wiąże się ze zmiennością dyskursu narracyjnego, o którym także wspomina literaturoznawczyni. Parafrazując, za wyznacznik wielkiej elipsy trzeba przyjąć strukturę elementów stanowiących bezpośredni kontekst, a zarazem swoistą ramę logiczną i artystyczną dla treści przemilczanych. Kontekst ten determinuje oczekiwania odbiorcy co do kompletności, spójności dzieła (tu warto przypomnieć niedosyt pozostawiany przez dzieła artysty). Wielka elipsa jest dominantą generującą jakości metafizyczne, co plasuje ich istotny sens w sferze znaczeń ulotnych, nieokreślonych, a brak spodziewanych treści staje się wymowny. Co

31 B. Pawłowska-Jądrzyk, op. cit., s. 83.

32 Zarówno w opowiadaniach, jak i w malarstwie Beksińskiego instancja narratora dysponuje zmienną wiedzą, co objawia się w przyjmowaniu różnych punktów widzenia i perspektyw w surrealistycznym i onirycznym widzeniu i przedstawianiu świata. 
istotne w kontekście odniesienia kategorii badaczki do prac Beksińskiego, wspomina ona także o tym, jak znaczącym komponentem postaciowania pośredniego jest sceneria ${ }^{33}$. Do tego należy dodać palimpsestowy charakter rzeczywistości ${ }^{34}$ oraz zderzenia różnych perspektyw (o perspektywie w dalszej części artykułu). „Jako narzędzie defamiliaryzacji rzeczywistości przedstawionej i figura znaczeń nieuchwytnych wyrzutnia tego rodzaju wydaje się [...] jedną z [...] [zasad organizacji - przyp. B.K.] pewnego typu dzieł otwartych, ożywiających umysł i wyobraźnię potencjałem myśli nieokreślonej”" Ws. Wszystkie te właściwości wskazują na eliptyczność zarówno malarstwa, jak i literatury Beksińskiego.

\section{TRANSPOZYCJE MEDIALNE W TWÓRCZOŚCI BEKSIŃSKIEGO}

Badanie grozy w dziełach Beksińskiego pozwala dostrzec transpozycje medialne stanowiące charakterystyczny element poetyki artysty. Ewa Szczęsna tłumaczy zjawisko transpozycji medialnej jako „realizowanie konwencji estetycznych, właściwości wzrokowych, słuchowych jakiegoś medium w ramach innego medium"36. W twórczości Beksińskiego zabiegi te potęgują efekt grozy.

W malarstwie sanoczanina transpozycje medialne polegają na zastosowaniu reprezentacji środków stylistycznych charakterystycznych dla literatury: metafory, wyolbrzymienia, oksymoronu, powtórzenia i ożywienia.

33 Ibidem, s. 94.

34 Jak wskazuje Ewa Paczoska, „Palimpsestowość ujawnia się w natłoku i zróżnicowaniu narracji i perspektyw". Zob. E. Paczoska, Wiktorianizm i rytmy rozwojowe powieści polskiej drugiej połowy XIX wieku. Rekonesans, [w:] Wiktorianie nad Tamiza $i$ nad Wisła, red. E. Paczoska, A. Budrewicz, Warszawa 2016, s. 204. Więcej na temat palimpsestowości twórczości Beksińskiego zob. B. Hamera, Przestrzeń w malarstwie i prozie Zdzisława Beksińskiego, Warszawa 2019 [praca magisterska napisana na Wydziale Polonistyki UW pod kierunkiem prof. Ewy Szczęsnej].

35 B. Pawłowska-Jądrzyk, op. cit., s. 89. O kompozycji otwartej obrazów i opowiadań Beksińskiego zob. B. Hamera, Przestrzeń w malarstwie i prozie Zdzisława Beksińskiego, op. cit., s. 58-63.

36 E. Szczęsna, Poetyka mediów, op. cit., s. 30. Zob. także: C. Balme, Wprowadzenie do nauki o teatrze, tłum. W. Dudzik, M. Leyko, Warszawa 2002, s. 204-205. 
Tymczasem w przypadku opowiadań są to typowe dla sztuki wizualnej gra perspektywą oraz punkty widzenia.

Za meta for ę w malarstwie uważam takie przedstawienie, w którym sensy dwóch widocznych elementów (stanowiących jedność) wchodząc w interakcję, tworzą nowe znaczenia naddane, inne niż te, które powstałyby w wyniku interpretowania tylko jednej części obiektu złożonego lub obu części, lecz w separacji ${ }^{37}$. Jako przykład może posłużyć poniższy obraz (il. 6), na którym widnieje budynek-twarz. Obiektu tego nie można rozłożyć na dwa i odczytywać tylko jako budynek lub tylko jako twarz, natomiast zespolenie obu tych rzeczy generuje nowe znaczenie i interpretację - być może obrazuje przestrzeń psychiczną, przestrzeń głowy, konstrukcję pustki psychicznej czy emocjonalnej, przestrzeń snów czy wspomnień, wyobrażeń (które to mogą przenosić do innych przestrzeni, związanych z jakimiś przeżyciami).

$\mathrm{Na}$ drugim obrazie (il. 7) widnieje łódź-trumna, która może symbolizować tułaczkę człowieka przez życie, będące jednocześnie drogą ku nieuniknionej śmierci. Łódź jest schronieniem, lecz jednocześnie jest ciasna i więzi w swoich granicach człowieka, który jest na nią skazany i który jest osamotniony - towarzyszą mu tylko niepokój i niepewność. Obraz ten może posłużyć także jako przykład drugiego rodzaju transpozycji, czyli w yolbr zymienia. Łódź-trumna, byt, istnienie człowieka są małe i wątłe w stosunku do bezkresu wieczności, kosmosu.

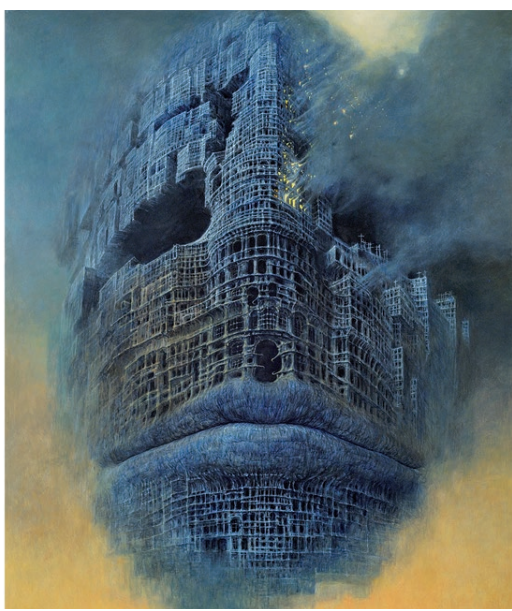

Il. 6

Wyolbrzymienie polega zatem na pokazywaniu rzeczy w innej skali niż normalnie, w rzeczywistym świecie. Omawiany efekt osiąga się przede wszystkim dzięki wykorzystaniu perspektywy żabiej lub ptasiej. Na kolejnym obrazie (il. 8) widać maleńką postać kroczącą w ciemności, w labiryncie zbudowanym z wielkich zakapturzonych

37 Na temat metafor i innych figur w malarstwie pisała w swoich pracach m.in. S. Wysłouch. Zob. np. S. Wysłouch, Literatura a sztuki wizualne, Warszawa 1994. 


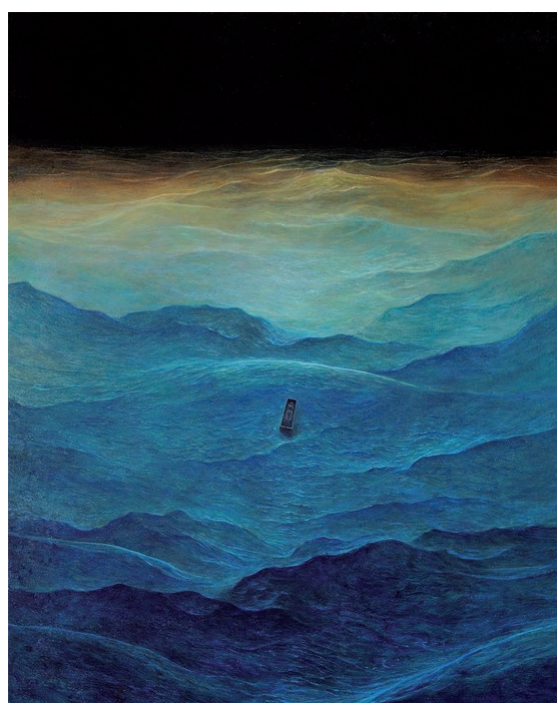

Il. 7

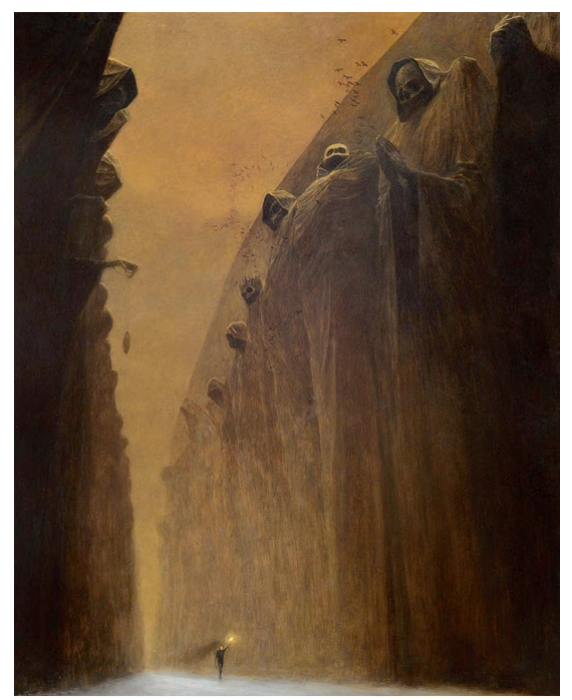

Il. 8

istot - wyglądających jak typowe wyobrażenie śmierci. Postać ta kroczy ze światełkiem, szuka drogi, być może wyjścia. Na następnym obrazie (il. 9) widać korytarz - jest ogromny, ukazany z perspektywy żabiej urasta do rangi niekończącego się, przytłaczającego.

Trzeci typ transpozycji to oksymoron, czyli zestawienie dwóch sprzecznych ze sobą cech. Zarówno na tym, jak i na wielu innych obrazach najczęściej pojawiającym się takim zestawieniem jest żywy trup ${ }^{38}$. Koń, zapewne jak i kobieta oraz jej dziecko nie mają prawa żyć - jest to niezgodne ze wszelkimi prawami natury. W świecie Beksińskiego jednak dokądś zmierzają, żyją (il. 10).

Jako czwarty przykład transpozycji wymienić można powtórze$\mathrm{n}$ ie. Jest to nagromadzenie podobnych elementów na jednym obrazie,

${ }^{38}$ Maria Janion pisze o wielu aspektach postrzegania w kulturze i literaturze bytów na granicy życia i śmierci. Według niej żywe trupy, wampiry czy manekiny to imitacja życia (zob. M. Janion, Wampir. Biografia symboliczna, Gdańsk 2008). Nic dziwnego, że tak licznie ukazują się w opowiadaniach Beksińskiego - świat jego sztuki składa się z wielu momentów i elementów granicznych, jest - lub może być - iluzją. 


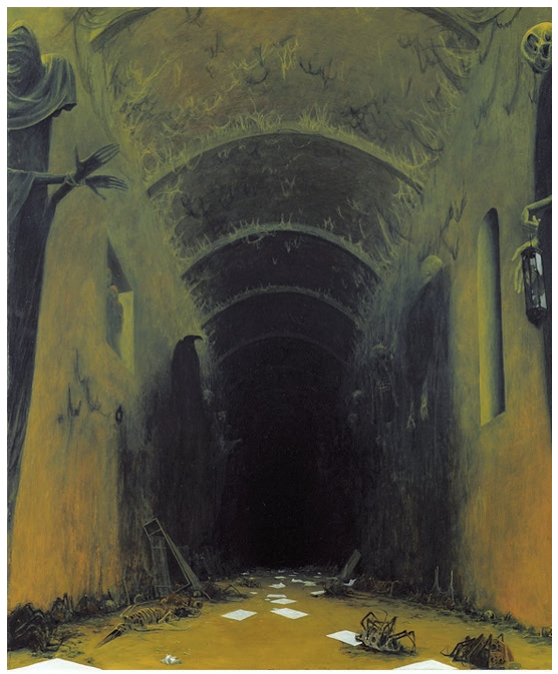

Il. 9

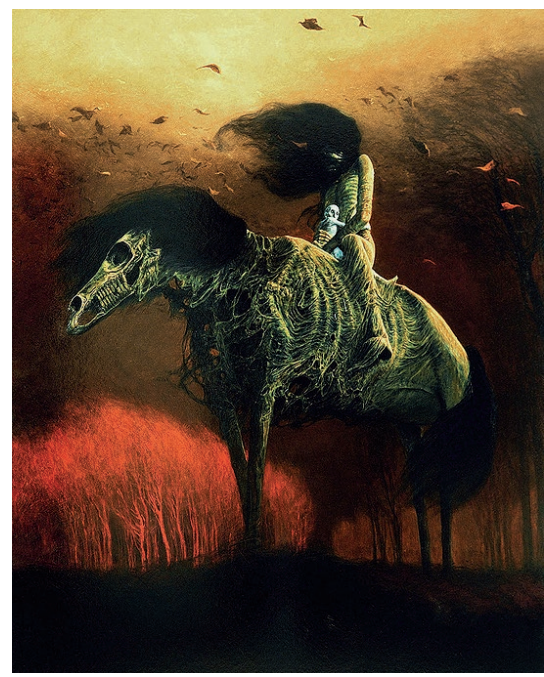

Il. 10

ale i powtarzających się motywów (czy ich ujęć) na wielu innych dziełach malarskich artysty. Powtórzenie ograniczone działaniem do ram jednego obrazu można zilustrować choćby za pomocą widocznego kolejnego przykładu (il. 11), na którym zauważalne jest zwielokrotnienie zawieszonych w powietrzu betonowych konstrukcji. Te unoszące się płyty ciągną się w nieskończoność, wydłużając granice świata.

W twórczości malarskiej artysty powtarzają się takie motywy i elementy, jak: krzesła, łuki (np. drzwi, okien), czaszki, kości, pale, unoszące się pod wpływem wiatru przedmioty, budynki, nagrobki, krzyże. Za przykład takiego powtórzenia obejmującego kilka dzieł może posłużyć zaprezentowane zestawienie trzech obrazów (il. 12-14), ilustrujących wejścia/wyjścia widziane na wprost. Można tu mówić o paralelizmie przestrzennym czy wręcz kalce semiotycznej, którą tworzą powtarzające się układy przestrzenne.

Warto wspomnieć, że powtórzenie to także częsty środek stosowany w prozie Beksińskiego. O ile nie można powiedzieć tego samego o innych figurach stylistycznych, ten typ pojawia się niezwykle często w opowiadaniach, wprowadzając zwykle motyw szaleństwa. 

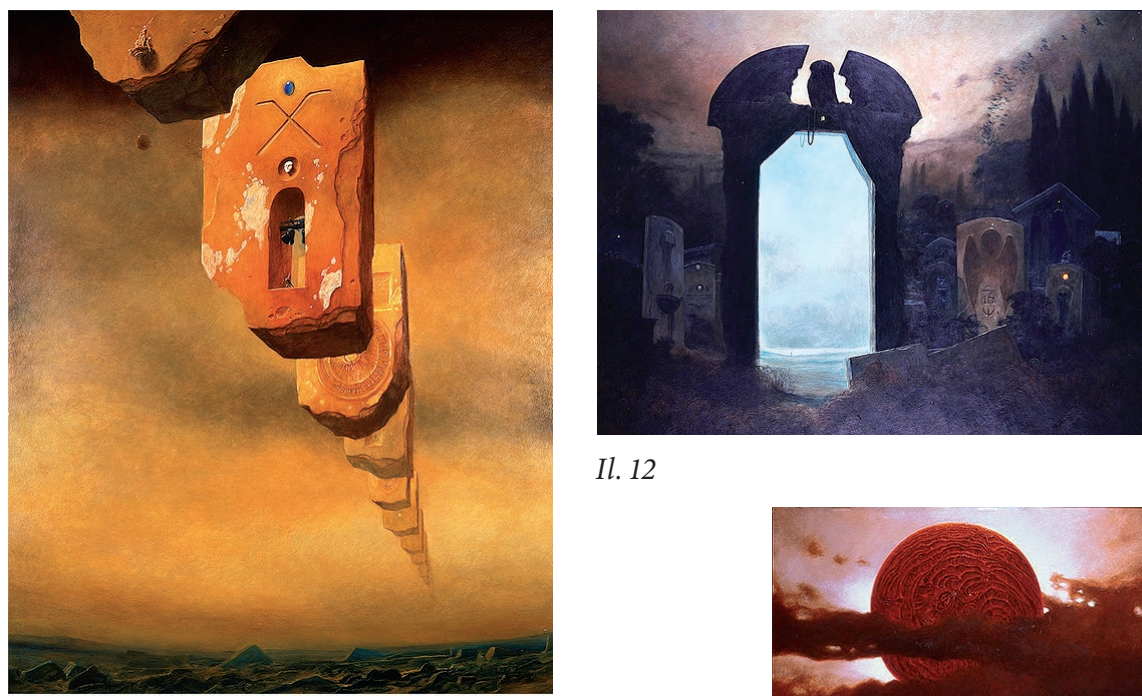

Il. 12

Il. 11

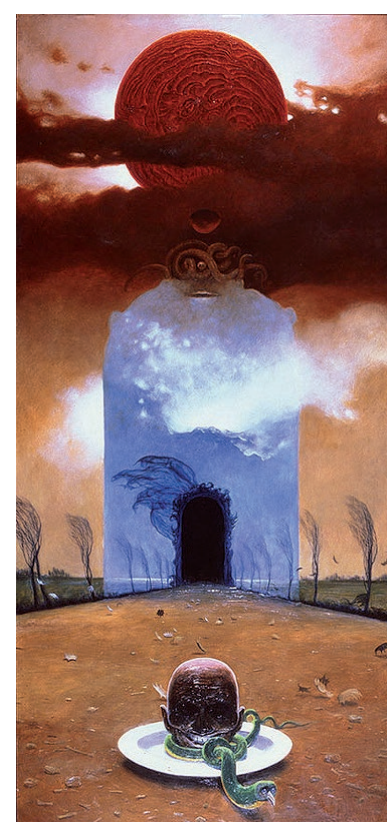

Il. 13 człowieka $\mathrm{z}$ takim widzeniem rzeczy, które nie jest odruchowe, komfortowe. Perspektywa często służy także pogłębieniu analizy rzeczywistości otaczającej narratora-bohatera. Jednakże sama potrzeba studiowania przestrzeni, zwykłej i codziennej - przynajmniej z pozoru - zadziwia i sprawia, że czytelnik staje się podejrzliwy - jakby na wzór narratora. Beksiński buduje nastrój pełen wątpliwości, braku zaufania. Taka postawa skłania do ograniczenia wiary 

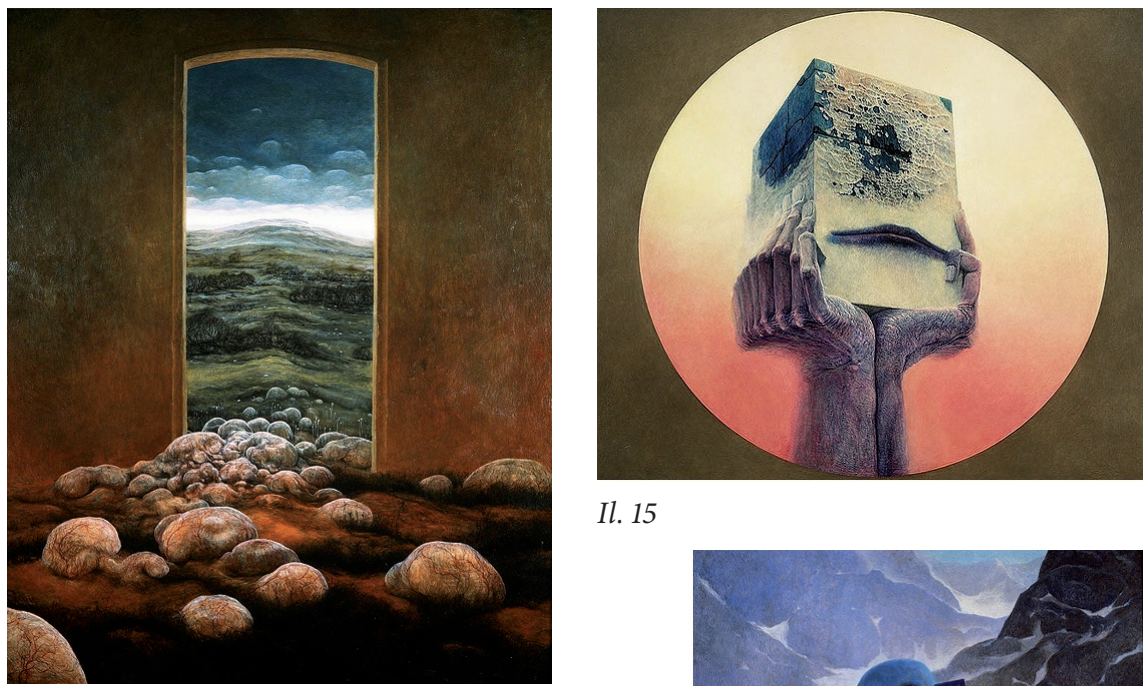

Il. 15

Il. 14

we własną wiedzę, w możliwości zmysłów, w prawa natury, fizyki, we wszystko to, czego w codziennym życiu człowiek nawet nie dostrzega.

Analiza perspektywicznych skrótów widocznych na popiersiu i twarzy kobiety zdaje się wskazywać, że odległość między nią a malarzem, który ją ma-

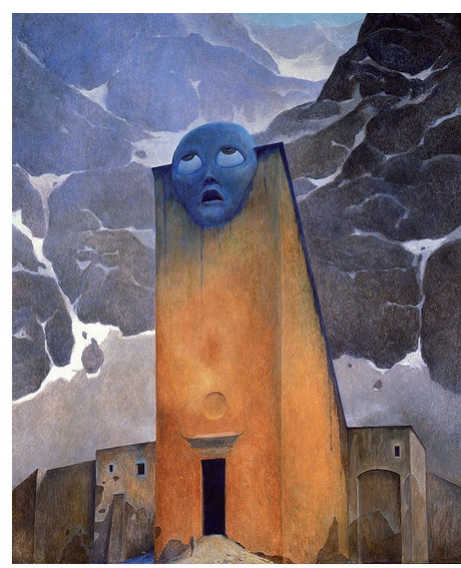

Il. 16 luje, wynosi około trzech metrów. [...]

Równie dobrze można by było przyjąć możliwość, że ściana tła znajduje się bardzo blisko i jest niezwykle mała, a stado ptaków przypomina rozmiarami rój pszczół, jak też że ściana tła znajduje się w odległości kilkuset metrów, jest olbrzymia niczym góra, a ptaki przypominają swoimi rozmiarami pterodaktyle ${ }^{39}$.

39 Z. Beksiński, Kobieta z portretu, [w:] idem, op. cit., s. 335-336. 


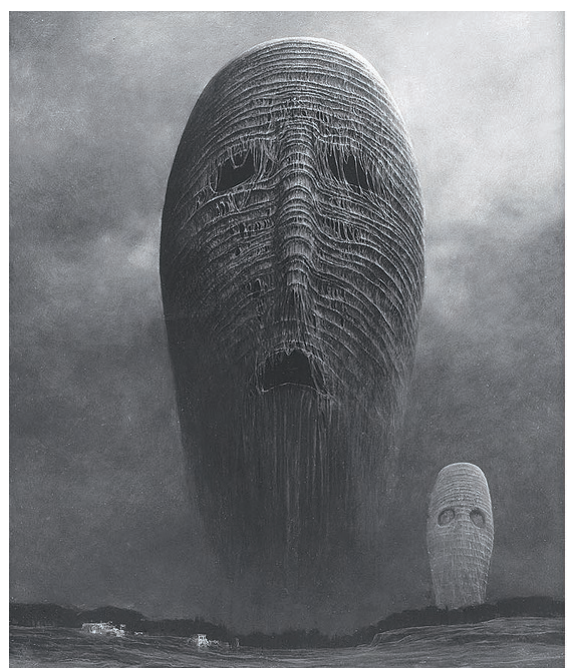

Il. 17

Operowanie różnymi punktami widzenia, uświadamianie ich istnienia, przywołuje skojarzenie $\mathrm{z}$ ciągłą obserwacją - $\mathrm{z}$ byciem obiektem obserwowanym lub obserwującym. To także nie wpływa na komfort czytelnika, który staje się nieufny wobec przestrzeni opowiadania. Beksiński nieustannie przypomina, że wiele rzeczy może się wydawać, że bardzo często widać tylko jedną stronę przedmiotu, obiektu czy też człowieka, psychiki, świata. Uświadamia, jak bardzo dostępność tylko jednego punktu widzenia w momencie obserwacji ogranicza wiedzę na temat rzeczywistości. Czy w takim świecie można ufać komukolwiek, skoro nie można zaufać sobie? Artysta zagłębia się w tę ułomność człowieka - jako tego, który widzi i odczuwa tylko wycinek - w sposób filozoficzny, bliski rozważaniom Kartezjusza, a nawet posuwa się do wątpienia, czy on sam, podmiot myślący, istnieje.

Można to nazwać seansem filmowym. Pewne rzeczy widać i pewne rzeczy słychać, o pewnych rzeczach istnieją informacje. [...] Widać jedynie to, co obejmuje sobą ekran, a i z tego nawet widać tylko jedną stronę - tę, która zwrócona jest w kierunku utrwalającej obraz kamery ${ }^{40}$.

Oprócz tego obserwacja często wiąże się u Beksińskiego z rolami odgrywanymi przez postaci z jego opowiadań. Role te dane są na całe życie, są jedynymi konstytuującymi postać danymi o niej samej, uzasadniającymi jej istnienie. Kiedy mowa o rolach, blisko już stąd do pojęcia theatrum mundi. Wizja świata jako teatru, ludzi jako marionetek, nad którymi coś znacznie

40 Idem, Piasek, [w:] op. cit., s. 142. 
większego i donioślejszego ma władzę, przytłaczała ludzi już w starożytności i ma tę moc po dziś dzień.

W kiosku widać teraz poruszającą się sylwetkę kobiety. [...] Musiała wejść od tyłu [...]. Wejście do kiosku jest od tyłu. Można go odwiedzać i opuszczać, nie będąc widzianym z miejsca, w którym znajduje się Numer Szesnasty. Należy tylko nieco się schylić i sterta skrzyń jest w stanie zakryć człowieka lub ludzi przed okiem obserwatora, jeśli naturalnie ten obserwator znajduje się w punkcie okupowanym w tej chwili przez Numer Szesnasty. Być może i dla wielu innych punktów dojście do kiosku jest ukryte ${ }^{41}$.

\section{GROZA OSWOJONA}

Do omówienia następnej cechy charakterystycznej twórczości Beksińskiego niezbędne jest przytoczenie kontekstu późnych dzieł artysty. Etap ten zaczął się w latach dziewięćdziesiątych i trwał do śmierci twórcy. Malarstwo z tego okresu jest spokojne, monobarwne, o niepewnej kresce i pełne rozmyć. Nie cieszy się ono taką popularnością, jak pełne rozmachu, symbolów i szczegółów malarstwo z okresu fantastycznego. Jest dość oszczędne w treści, a sam Beksiński zdaje się już nie artykułować na obrazach swoich egzystencjalnych wątpliwości ani ostrych, zdecydowanych opinii na temat życia i śmierci. Być może kolejne tragiczne przeżycia, które towarzyszyły artyście, spowodowały jego odwrót od walki z niemocą człowieka. Artysta wydaje się pogodzony z tym, jak różne twarze przybiera życie, jak rzuca człowieka w różne miejsca i sytuacje, że prowadzi go do nieuniknionego - do śmierci. Mimo że obrazów z tego okresu nie można nazwać pogodnymi (zresztą w całej jego twórczości nie znajdziemy ani jednego przykładu na twórczość pogodną), Beksiński znajduje piękno i przyjemność szarego dnia - dnia codziennego, dnia przybliżającego do śmierci. I choć nie jest to takie piękno, jakiego człowiek oczekuje, jakiego być może sam Beksiński próbował doszukać się w życiu - piękna idealnego - to jest to element zaskakująco odmienny od tego, do czego przyzwyczaił odbiorców latami twórczości. Piękno to jest nieidealne, skarykaturyzowane, wątpliwe, być może nawet śmieszne, kiedy nazywa się je pięknem - ale Beksiński je dostrzega. Artysta widzi

${ }^{41}$ Idem, Zamach, [w:] op. cit., s. 204. 
traumy, przeżycia, rozterki drzemiące w każdym z ludzi - i to także ukazuje. Rezultatem jest efekt, który można by określić jako grozę oswojoną. Nazywam w ten sposób zjawisko, które polega na umiejscowieniu elementów tradycyjnie wywołujących grozę w kontekstach i sytuacjach znanych, codziennych, kojarzonych pozytywnie, przez co efekt grozy ulega redukcji. Groza ta modyfikuje w malarstwie artysty działanie figur wcześniej zastosowanych przez Beksińskiego do jej spotęgowania (zwłaszcza oksymoronu, aluzji i ożywienia). Zamienia ich wcześniejsze oddziaływanie wzmagające poczucie grozy w odbiorcy na oswojenie emocji i strachu wcześniej wywołanych w nim przez owe figury (il. 18-21).

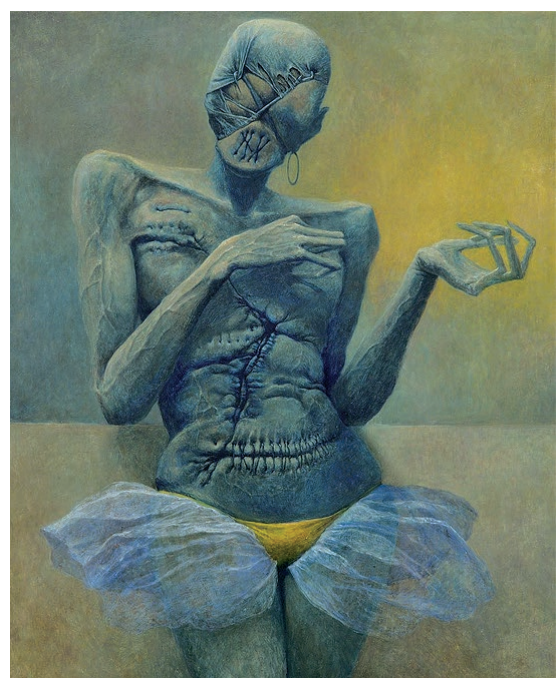

Il. 18

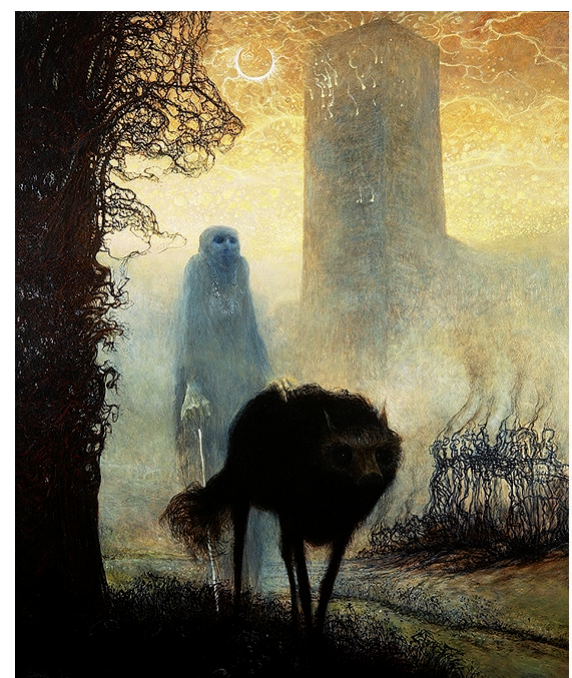

Il. 19 

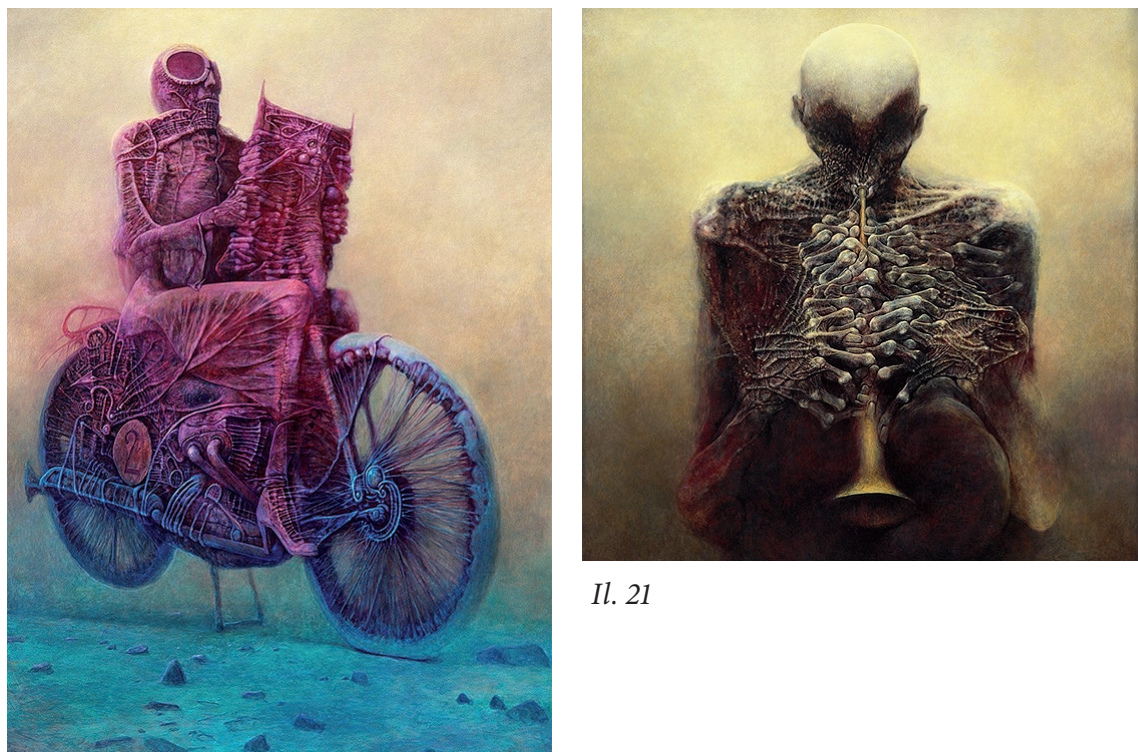

Il. 21

Il. 20

Artysta przedstawia m.in. kobietę, być może baletnicę, w zmysłowej delikatnej pozie. Obrazuje spacer starszego człowieka z towarzyszem podobnym do psa, pokazuje motocyklistę czytającego gazetę czy człowieka grającego na trąbce. Postacie te, ich otoczenie, są nadal nieprzyjemne - dostrzegalne są rany na ciele, kości, trupiość postaci, przestrzeń jest mglista, pusta, zagadkowa. Jednakże obrazy te wywołują współczucie, czułość, spokój, nie straszą już, nie przytłaczają tak silnie, jak wcześniejsze. Odbiorca może odnaleźć w nich siebie lub kogoś bliskiego. Twórca zobrazował miłość, pożądanie, odpoczynek, relaks w taki sposób, w jaki występują one w życiu. Nie są doskonałe, lecz często okraszone trudem, jaki kosztowały, cierpieniem, czasem. Wydaje się, że Beksiński znalazł punkt graniczny między życiem a śmiercią i w tym miejscu pozostał, być może odnajdując w nim jedyne pewne constans (il. 22-24). 


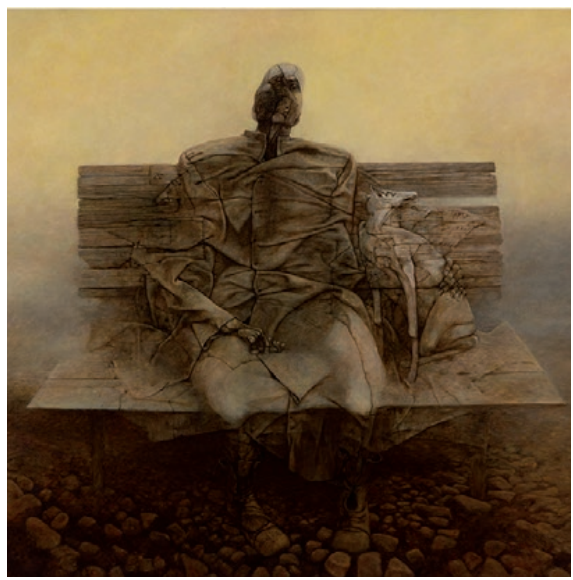

Il. 22

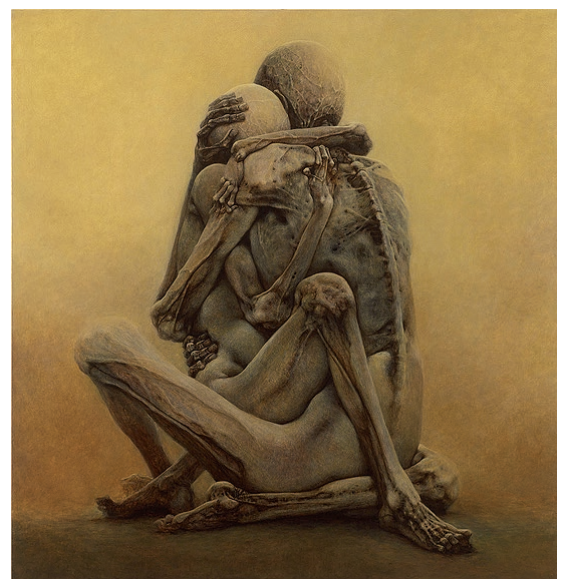

Il. 23

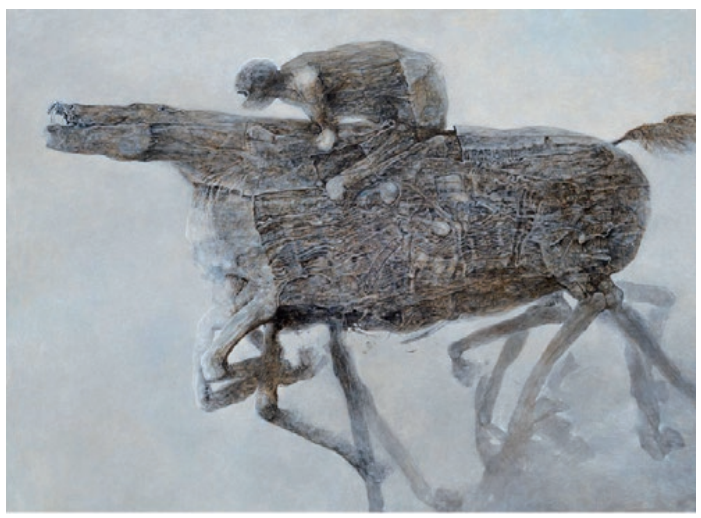

Il. 24

\section{PODSUMOWANIE}

Starannie dopracowana twórczość Beksińskiego - choć różniąca się bądź w zależności od materii artystycznej, w której tworzył, bądź od czasu, kiedy tworzył - układa się w jedną konsekwentną wizję świata. Wizję artysty, w którym było dużo niepokoju, niezgody na panujące realia, zarówno polityczne, jak i te zupełnie niezależne od ludzi, rządzące się prawami natury. To ponure spojrzenie na życie, rolę człowieka i jego możliwości znajduje oddźwięk nie tylko w surrealistycznych obrazach, czarno-białej dobitnej 
fotografii czy równie mocnych fotomontażach - wyrażane jest także na kartkach opowiadań czy dzienników. Groza bijąca z twórczości samotnika z Sanoka wybrzmiewa $\mathrm{z}$ każdego drobnego elementu jego dzieł: z przestrzeni, jaką konstruował, z postaci, które w niej umieszczał, kolorystyki, którą barwił świat przedstawiony. Efekt ten wzmacniał swoim interdyscyplinarnym, wszechstronnym talentem do przedstawiania swojego niezwykłego widzenia świata. Czerpiąc z różnych dziedzin sztuki, przenosił typowe dla nich rozwiązania na obszar innych sztuk, w których się realizował.

\section{Bibliografia}

Christopher Balme, Wprowadzenie do nauki o teatrze, tłum. W. Dudzik, M. Leyko, PWN, Warszawa 2002.

Wiesław Banach, „Nadal szukać swojej drogi”. Zdzisław Beksiński - człowiek wielu talentów, [w:] Z. Beksiński, Opowiadania, red. T. Chomiszczak, BOSZ, Olszanica 2016. Zdzisław Beksiński, Opowiadania, red. T. Chomiszczak, BOSZ, Olszanica 2016.

Henryk Brzozowski, Odnaleźć w sercu i pod powiekami, „Tygodnik Powszechny” 1977, nr 25.

Tomasz Chomiszczak, Nota wydawnicza, [w:] Beksiński Zdzisław, Opowiadania, red. T. Chomiszczak, BOSZ, Olszanica 2016.

Maria Janion, Wampir. Biografia symboliczna, słowo/obraz terytoria, Gdańsk 2008.

Bogna Hamera, Przestrzeń w malarstwie i prozie Zdzisława Beksińskiego, 2019, praca magisterska napisana na Wydziale Polonistyki UW pod kierunkiem prof. Ewy Szczęsnej.

Anita Has-Tokarz, Horror w literaturze wspótczesnej i filmie, Lublin 2010.

Marcel Mauss, Socjologia i antropologia, tłum. M. Król, K. Pomian, J. Szacki, PWN, Warszawa 1973.

Ksenia Olkusz, Gotyckie światy wspótczesnej grozy, [w:] Światy grozy, red. K. Olkusz, Kraków 2016.

Ksenia Olkusz, O grozie i postgrozie. Dyskursy - konwencja - estetyka, [w:] Groza i postgroza, red. K. Olkusz, B. Szymczak-Maciejczyk, Ośrodek Badawczy FactaFicta, Kraków 2018.

Ryszard Nycz, Tekstowy świat. Poststrukturalizm a wiedza o literaturze, Universitas, Kraków 2000.

Ewa Paczoska, Wiktorianizm i rytmy rozwojowe powieści polskiej drugiej połowy XIX wieku. Rekonesans, [w:] Wiktorianie nad Tamiza i nad Wisła, red. E. Paczoska, A. Budrewicz, Wydawnictwo Wydziału Polonistyki UW, Warszawa 2016.

Brygida Pawłowska-Jądrzyk, „Wielka elipsa” w narracji literackiej i filmowej. („Piknik pod Wisząca Skała”"), [w:] Komparatystyka dzisiaj, red. E. Kasperski, E. Szczęsna, Wydawnictwo Elipsa, Warszawa 2011. 
Bożena Płonka-Syroka, Wstęp, [w:] Groza. Społeczno-kulturowe mechanizmy kreowania emocji, red. B. Płonka-Syroka, M. Szymczak, Oficyna Wydawnicza Arboretum, Wrocław 2010.

Łukasz Sarowski, Robot społeczny - wprowadzenie do zagadnienia, „Roczniki Kulturoznawcze" 2017.

Ewa Szczęsna, Poetyka mediów. Polisemiotyczność, digitalizacja, reklama, Wydawnictwo Wydziału Polonistyki UW, Warszawa 2007.

Yi-Fu Tuan, Ciało, relacje międzyludzkie i wartości przestrzenne, [w:] idem, Przestrzeń i miejsce, tłum. A. Morawińska, PIW, Warszawa 1987.

Ewa Wójtowicz, $W$ stronę doliny niesamowitości, [w:] Bio-techno-logiczny świat: bio art oraz sztuka technonaukowa $w$ czasach posthumanizmu i transhumanizmu, red. P. Zawojski, 13muz, Instytucja Kultury Miasta Szczecin, Szczecin 2015.

Seweryna Wysłouch, Literatura a sztuki wizualne, PWN, Warszawa 1994.

\section{Źródła ilustracji}

Il. 1. https://beks.pl/wp-content/uploads/2016/11/S-6110low.jpg [dostęp 4.02.2021].

Il. 2. https://pbs.twimg.com/media/EDC1EaZWkAAL_ro.jpg:large [dostęp 4.02.2021]. Il.3.https://64.media.tumblr.com/6917fd703232bb669364a5eff9de0ab1/tumblr_p2yu6r5QQZ1uz2g97o1_1280.jpg [dostęp 4.02.2021].

Il. 4. https://beks.pl/wp-content/uploads/2016/10/S-2249low.jpg [dostęp 4.02.2021].

Il. 5. https://beks.pl/wp-content/uploads/2016/11/S-2259alow.jpg [dostęp 4.02.2021].

Il. 6. https://beks.pl/wp-content/uploads/2016/10/S-2282-popra.jpg [dostęp 4.02.2021].

Il. 7. https://beks.pl/wp-content/uploads/2016/11/S-6103low.jpg [dostęp 4.02.2021].

Il. 8. https://beks.pl/wp-content/uploads/2016/10/S-2257low.jpg [dostęp 4.02.2021].

Il. 9. https://beks.pl/produkt/zdzislaw-beksinski-obraz-ah76/ [dostęp 4.02.2021].

Il. 10. https://beks.pl/wp-content/uploads/2018/12/xg1_08_lowres.jpg [dostęp 4.02.2021].

Il. 11. https://beks.pl/wp-content/uploads/2016/10/103x123-cm-1973_low_res.jpg [dostęp 4.02.2021].

Il. 12. http://beksinski.dmochowskigallery.net/gfx/db/big/002482.jpg [dostęp 4.02.2021].

Il. 13. http://beksinski.dmochowskigallery.net/gfx/db/bigger/003423.jpg [dostęp 4.02.2021].

Il. 14. https://beks.pl/wp-content/uploads/2018/12/61x73-cm-1977_lowres.jpg [dostęp 4.02.2021].

Il. 15. http://beksinski.dmochowskigallery.net/galeria_zoom.php?artist=52\&picture $=2471$ [dostęp 4.02.2021].

Il. 16. http://beksinski.dmochowskigallery.net/gfx/db/big/003424.jpg [dostęp 4.02.2021].

Il. 17. http://beksinski.dmochowskigallery.net/gfx/db/bigger/003330.jpg [dostęp 4.02.2021].

Il. 18. https://beks.pl/wp-content/uploads/2016/10/S-2270_low.jpg [dostęp 4.02.2021]. 
Il. 19. https://beks.pl/wp-content/uploads/2017/05/7_AC77_new_low_res_65x79_70x85. jpg [dostęp 4.02.2021].

Il. 20. https://beks.pl/wp-content/uploads/2017/05/10_AC86_new_low_res_60x82_66 x91.jpg [dostęp 4.02.2021].

Il. 21. https://beks.pl/wp-content/uploads/2017/05/12_AD83_new_low_res_74x74_ 83x83.jpg [dostęp 4.02.2021].

Il. 22. https://beks.pl/wp-content/uploads/2017/02/579A0892_lowres.jpg [dostęp 4.02.2021].

Il. 23. https://beks.pl/wp-content/uploads/2017/09/AA84_lowres.jpg [dostęp 4.02.2021].

Il. 24. https://beks.pl/wp-content/uploads/2016/10/S-5639low.jpg [dostęp 4.02.2021].

\section{Figures of Dread in the Literary Works and Paintings by Zdzisław Beksiński}

The author of this article focuses on the category of dread which is characteristic of Beksiński's works. It is an original phenomenon because of the tools that create it and its influence on the poetics of the artistic text. The most important areas of the artist's literary works and paintings in which he operated with dread, were space, characters and colors. Due to the similarity of means of expression shaping dread in stories and paintings, one can speak of transmedia figures of dread in Beksiński's work, i.e. metaphor, exaggeration, oxymoron, repetition, animation, play with the perspective and points of view. These figures coexist with each other, interact with each other in the process of creating a unique world of dread, characteristic only to Beksiński. On the other hand, dread itself affects the tools that make it up and transforms the effect of their operation. The author of the article calls such a phenomenon 'acquainted dread' - the action of the figures used, initially causing dread, is reversed and means that the presented elements - despite the clear features causing fear - cease to be its source for the recipient.

Keywords: Zdzisław Beksiński, figures of dread, medial transposition, acquainted dread, horror

Data otrzymania tekstu: 1.06.2020 r.

Data zakończenia procesu recenzyjnego: 25.01.2021 r.

Data akceptacji tekstu do druku: 1.02.2021 r. 
